\title{
Efektivitas Pemberian Pelet Indigofera terhadap Pertumbuhan dan Kualitas Daging Kambing Boerka
}

\section{(Effectiveness of Feeding Indigofera's Pellet on Growth and Meat Quality of Boerka Goats)}

\author{
Antonius, Solehudin, Tarigan A, Simanihuruk K, Ginting SP \\ Loka Penelitian Kambing Potong Sei Putih \\ Galang 20585 Deliserdang, Sumatera Utara \\ solehudintaher02@gmail.com
}

\begin{abstract}
Indigofera zollingeriana is a forage which containing good quality of nutrition and also antioxidant. This study was aimed to determine the effectiveness of Indigofera zollingeriana's pellets on growth and meat quality of Boerka goat. Eighteen of Boerka goats aged 10-11 month with an average initial body weight of $20.47 \pm 2.79 \mathrm{~kg}$ was used. The study used Randomized Block Design (RBD) with three treatments, namely: Pennisetum purpureum cv. Mott + Concentrate $\left(\mathrm{R}_{1}\right), \mathrm{R}_{1}+$ Indigofera's Pellet $5 \mathrm{~g} / \mathrm{kg} \mathrm{BW} / \mathrm{h} / \mathrm{d}\left(\mathrm{R}_{2}\right)$, and $\mathrm{R} 1$ + Indigofera's Pellet $10 \mathrm{~g} / \mathrm{kg} \mathrm{BW} / \mathrm{h} / \mathrm{d}\left(\mathrm{R}_{3}\right)$. Each treatments was replicated six times. Data were analyzed by Analysis of variance (ANOVA) and continued with Duncan's multiple range test if there were differences. The results showed that the feeding of Indigofera's pellets had a significant effect $(\mathrm{P}<0.05)$ on average daily gain and meat tenderness but did not have a significant effect $(\mathrm{P}>0.05)$ on carcass percentage, $\mathrm{pH}$, cooking losses and water holding capacity of Boerka mutton.
\end{abstract}

Key words: Indigofera zollingeriana, growth, meat quality, Boerka

\begin{abstract}
ABSTRAK
Indigofera zollingeriana merupakan hijauan pakan ternak yang mengandung kualitas nutrisi yang baik dan juga antioksidan. Penelitian ini bertujuan untuk mengetahui efektivitas pelet Indigofera zollingeriana terhadap pertumbuhan dan kualitas daging kambing Boerka. Ternak yang digunakan dalam penelitian ini adalah kambing Boerka umur 10-11 bulan

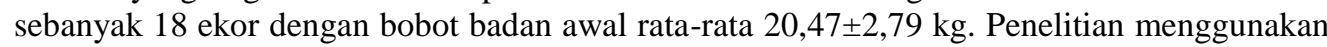
Rancangan Acak Kelompok (RAK) dengan tiga perlakuan yaitu: Pennisetum purpureum cv. Mott+Konsentrat $\left(\mathrm{R}_{1}\right), \mathrm{R}_{1}+$ Pelet Indigofera $5 \mathrm{~g} / \mathrm{kg} \mathrm{BB} / \mathrm{e} / \mathrm{h}\left(\mathrm{R}_{2}\right)$, dan $\mathrm{R}_{1}+$ Pelet Indigofera 10 $\mathrm{g} / \mathrm{kg} \mathrm{BB} / \mathrm{e} / \mathrm{h}\left(\mathrm{R}_{3}\right)$. Masing-masing perlakuan diulang sebanyak enam kali. Data dianalisis menggunakan Analysis of variance (ANOVA) dan dilanjutkan dengan uji jarak berganda Duncan jika terdapat perbedaan. Hasil penelitian menunjukkan pemberian pelet Indigofera memberikan pengaruh yang nyata $(\mathrm{P}<0,05)$ terhadap pertambahan bobot badan harian dan keempukan daging tetapi tidak memberikan pengaruh yang nyata $(\mathrm{P}>0,05)$ terhadap persentase karkas, $\mathrm{pH}$, susut masak dan daya mengikat air daging kambing Boerka.
\end{abstract}

Kata kunci: Indigofera zollingeriana, pertumbuhan, kualitas daging, Boerka

\section{PENDAHULUAN}

Permintaan daging yang berkualitas dengan kandungan nutrisi tinggi, rendah kolesterol dan empuk semakin meningkat seiring dengan semakin tingginya tingkat 
pendidikan masyarakat. Aspek food safety dan food higiene dari produk ternak menjadi perhatian serius dari konsumen internasional. Pemenuhan kebutuhan kambing untuk upacara keagamaan (qurban dan aqiqah) baik di Indonesia maupun negara-negara tujuan ekspor juga memprasyaratkan aspek tersebut. Faktor utama yang menjadi pertimbangan adalah proses produksi yang memenuhi konsep clean, green, and ethical (CGE) (Martin \& Ferasyi 2010). Dengan demikian, aspek keamanan dan gizi pangan, baik dari kesehatan manusia maupun kesejahteraan hewan harus diperhatikan dalam pengembangan usaha peternakan yang berorientasi masa depan.

Produk-produk olahan daging sangat membutuhkan kelembutan, tingginya kandungan protein, warna yang stabil dan daya simpan yang tinggi. Penelitian beberapa tahun terakhir menunjukkan bahwa oksidasi lemak memiliki peran terhadap penurunan kualitas daging (Zhong et al. 2009). Oksidasi lemak pada daging menghasilkan berbagai turunan produk yang menyebabkan perubahan warna, kehilangan berat, kehilangan bau dan rasa, perubahan nilai nutrisi dan pengurangan umur simpan (Nissen et al. 2000). Oleh karena itu, penting untuk mengontrol perubahan ini dalam pengembangan produk daging yang lebih baik.

Tubuh memiliki beberapa mekanisme untuk mencegah terjadinya oksidasi, diantaranya aktivitas enzim superoxide dismutase (SOD), catalase (Cat) dan glutathione peroxidase (GSH-Px) (Zhong 2009). Disamping itu, kestabilan oksidatif daging juga ditentukan oleh adanya beberapa anti oksidan dari luar tubuh seperti vitamin $\mathrm{E}$ dan Vitamin A dalam memperlambat oksidasi lemak dan meningkatkan kestabilan warna. Beberapa anti oksidan sintetik sudah tersedia dengan mudah dan secara umum sudah digunakan dalam produksi makanan. Namun, anti oksidan sintetik tersebut dilaporkan memiliki potensi resiko karsinogenik. Oleh karena itu, penggunaan anti oksidan alami untuk menghambat efek negatif oksidasi lemak banyak diteliti belakangan ini (Sanchez et al. 2003).

Daun Indigoferra zollingeriana memiliki kandungan vitamin A dan B-karoten yang cukup tinggi, yaitu sekitar 3828.79 IU/100g dan $507.6 \mathrm{mg} / \mathrm{kg}$ (Palupi et al. 2014). Penambahan karatenoid dalam pakan broiler terbukti menghasilkan daging yang mengandung anti oksidan tinggi dan rendah kolesterol karena $\beta$-carotene berperan penting dalam mengurangi reaksi radikal bebas pada daging dan secara signifikan menghambat oksidasi lemak (Tavares et al. 2011; Kim et al. 2013). Pemberian daun Indigofera zollingeriana sebagai anti oksidan pada ternak kambing untuk meningkatan kualitas daging belum banyak diteliti sehingga penelitian efektivitas daun Indigofera zollingeriana terhadap pertumbuhan dan kualitas daging perlu dilakukan.

\section{MATERI DAN METODE}

Penelitian dilakukan pada bulan Februari sampai dengan September 2018 di Loka Penelitian Kambing Potong, Sei Putih Kabupaten Deli Serdang Provinsi Sumatera Utara. Pakan fungsional yang digunakan dalam penelitian ini adalah pelet daun Indigofera zollingeriana. Daun Indigofera zollingeriana dipanen dan dijemur selama 2 hari dengan suhu $30^{\circ} \mathrm{C}$ sampai kering untuk selanjutnya digiling halus dengan saringan $0,5 \mathrm{~mm}$. Tepung daun Indigofera zollingeriana dicampur secara homogen dengan molasses, tepung gaplek, garam dan mineral dengan perbandingan 90: 3: 5: 1: 1 untuk selanjutnya dibuat menjadi pellet. Daun Indigofera zollingeriana segar dan pellet diambil masingmasing sebanyak 200 gram sebagai sampel analisis kandungan nutrisi. Analisis dilakukan menggunakan metode AOAC (2012). Hasil analisis kandungan nutrisi pelet Indigofera: 
BK 85,16\%; PK 23,69\%; LK 3,24\%; dan SK 14,01\% (Laboratorium Pengujian Loka Penelitian Kambing Potong).

Uji biologis menggunkan kambing Boerka jantan umur 10-11 bulan dengan bobot badan awal rata-rata $20,47 \pm 2,79 \mathrm{~kg}$. Kambing didistribusikan secara acak sesuai perlakuan (6 ekor/perlakuan) dan ditempatkan dalam kandang individu yang dilengkapi dengan tempat pakan dan minum. Penelitian dirancang dengan rancangan acak kelompok dengan 6 kelompok (berdasarkan bobot badan) sebagai ulangan. Perlakuan yang diberikan pada uji pellet indigofera adalah sebagai berikut:

R1 : Pennisetum purpureum cv. Mott + konsentrat (pakan kontrol)

$\mathrm{R} 2: \mathrm{R} 1+$ Pelet daun Indigofera zollingeriana $(5 \mathrm{~g} / \mathrm{kg} \mathrm{BB} / \mathrm{e} / \mathrm{h})$

$\mathrm{R} 3: \mathrm{R} 1+$ Pelet daun Indigofera zollingeriana $(10 \mathrm{~g} / \mathrm{kg} \mathrm{BB} / \mathrm{e} / \mathrm{h})$

Pakan terdiri dari hijauan dan konsentrat dengan perbandingan 60:40. Konsentrat diberikan setiap pagi hari sebanyak $2,4 \%$ bobot badan, sedangkan hijauan segar diberikan sebanyak 1,6\% bobot badan (dalam bahan kering). Pelet daun Indigofera zollingeriana diberikan sebelum pemberian konsentrat. Air minum diberikan secara ad libitum. Ternak dibiasakan dengan perlakuan pakan serta kondisi kandang dan lingkungan sebelum pengumpulan data percobaan.

Penimbangan ternak dilakukan setiap 2 minggu sekali untuk penyesuaian pemberian pakan. Jumlah pemberian dan sisa pakan selama percobaan ditimbang untuk menghitung tingkat konsumsi pakan. Konsumsi bahan kering dan bahan organik diperoleh dengan cara mengalikan kandungan bahan kering dan bahan organik pakan dengan jumlah pakan yang dikonsumsi. Pertambahan bobot hidup harian dihitung berdasarkan bobot badan akhir dan bobot badan awal selama periode percobaan.

Penyembelihan ternak dilakukan pada akhir penelitian untuk mengetahui kualitas daging. Penyembelihan dan pemeriksaan kualitas daging dilakukan sesuai metode Aqsha et al. (2011). Prosedur pemotongan ternak dilakukan secara Islami dengan memotong ternak pada bagian leher hingga vena jugularis, oesofagus dan trakea terputus agar terjadi pengeluaran darah yang sempurna dan darah yang keluar ditampung kemudian ditimbang. Ternak digantung pada bagian kaki belakang, dilakukan pengulitan dan pengeluaran alat reproduksi, limpa, hati, jantung, paru-paru, alat pencernaan, empedu dan pankreas kecuali ginjal agar diperoleh karkas segar. Karkas segar dilayukan selama 3 jam pada suhu $160^{\circ} \mathrm{C}$. Selanjutnya, karkas dibagi menjadi 2 bagian secara simetris menjadi bagian kanan dan kiri. Sampel daging diambil dari bagian karkas sebelah kanan yaitu pada otot longissimus dorsi (LD) yang diambil pada bagian lain. Berat sampel daging dari masing-masing otot untuk analisis kimia adalah 100 gram. Sampel daging dimasukkan ke dalam plastik kemudian dibungkus dengan alumunium foil dan diberi label, kemudian dibawa ke laboratorium untuk diuji sifat fisiknya.

Data yang diperoleh dianalisis dengan sidik ragam dan apabila terdapat perbedaan yang nyata $(\mathrm{P}<0,05)$ antar perlakuan, maka analisis dilanjutkan dengan uji jarak berganda Duncan (Steel \& Torrie 1990).

\section{HASIL DAN PEMBAHASAN}

\section{Pertambahan Bobot Badan Harian (PBBH)}

Rataan konsumsi bahan kering dan bahan organik serta pertambahan bobot hidup harian kambing Boerka yang diberi pelet Indigofera zolingeriana disajikan pada Tabel 1. 
Tabel 1. Konsumsi bahan kering, konsumsi bahan organik dan pertambahan bobot badan harian kambing Boerka yang diberi pelet Indigofera

\begin{tabular}{lcccc}
\hline \hline \multirow{2}{*}{ Parameter } & R1 & R2 & R3 & Signifikasi \\
\cline { 2 - 4 } & $533,70 \pm 125,48^{\mathrm{a}}$ & $705,29 \pm 103,13^{\mathrm{b}}$ & $782,93 \pm 138,11^{\mathrm{b}}$ & 0,01 \\
\hline $\begin{array}{l}\text { Konsumsi bahan } \\
\text { kering (g/e/h) }\end{array}$ & & & \\
$\begin{array}{l}\text { Konsumsi bahan } \\
\text { organik (g/e/h) }\end{array}$ & $474,14 \pm 112,27^{\mathrm{a}}$ & $625,50 \pm 92,02^{\mathrm{b}}$ & $692,58 \pm 123,12^{\mathrm{b}}$ & 0,01 \\
PBBH (g/e/h) & $67,65 \pm 25,64^{\mathrm{a}}$ & $123,77 \pm 43,24^{\mathrm{b}}$ & $90,69 \pm 25,26^{\mathrm{ab}}$ & 0,03 \\
\hline
\end{tabular}

Superskrip huruf yang berbeda pada kolom yang sama menunjukkan perbedaan yang nyata $(\mathrm{P}<0,05)$

Pertambahan bobot hidup harian kambing yang diberi pellet Indigofera zolingeriana lebih tinggi $(\mathrm{P}<0,05)$ 82,96\% dan 34,06\% dibandingkan dengan kontrol $\left(\mathrm{R}_{1}\right)$. Lebih tingginya $\mathrm{PBBH}$ ini disebabkan karna jumlah bahan kering dan bahan organik pakan yang dikonsumsi oleh kambing yang diberi pelet Indigofera zolingeriana lebih tinggi $(\mathrm{P}<0,05)$ dibandingkan dengan kontrol (R1). Van Soest (1994) menyatakan bahwa asupan nutrien tercerna akan meningkat sejalan dengan peningkatan konsumsi BK.

Pertambahan bobot badan merupakan kemampuan ternak untuk mengubah nutrisi pakan menjadi daging dan merupakan peubah yang digunakan untuk menilai kualitas bahan pakan. Sesuai dengan Thalib (2004) yang menyatakan bahwa pertambahan bobot badan sebanding dengan ransum yang dikonsumsi. Pemberian pelet Indigofera mampu meningkatkan bobot badan daripada yang tidak diberi Indigofera. Hal ini menunjukkan bahwa kandungan nutrisi terutama protein dapat meningkatkan bobot badan ternak. Hasil perhitungan menunjukkan bahwa R2 dan R3 mengkonsumsi tambahan protein yang berasal dari pelet Indigofera masing-masing sebanyak $1 \mathrm{~g} / \mathrm{kg}$ BB dan $2 \mathrm{~g} / \mathrm{kg} \mathrm{BB}$. Sehingga diperkirakan perbedaan PBBH antara R2 dan R3 dengan R1 disebabkan karena adanya tambahan konsumsi protein tersebut. Kandungan protein dalam bahan pakan adalah salah satu faktor yang dapat meningkatkan bobot badan ternak (National Research Center 2004). PBBH pada R2 lebih tinggi daripada R3 yang berbanding terbalik dengan konsumsi bahan kering, konsumsi bahan organik dan tambahan konsumsi protein dari pelet Indigofera. Kandungan flavenoid pada Indigofera berpengaruh dalam menurunkan pertambahan bobot badan karena dapat menurunkan kandungan lemak dalam tubuh sebagaimana menurut Widyamanda et al. (2013) yang menyebutkan bahwa kandungan flavenoid dapat menurunkan kadar lemak tubuh.

\section{Karakteristik karkas dan sifat fisik daging}

Karakteristik karkas dan kualitas daging Boerka yang diberi pelet Indigofera zolingeriana disajikan pada Tabel 2. 
Tabel 2. Karakteristik karkas dan kualitas daging kambing Boerka yang diberi pelet Indigofera zolingeriana

\begin{tabular}{lcccc}
\hline \hline \multirow{2}{*}{ Parameter } & \multicolumn{3}{c}{ Perlakuan } & \multirow{2}{*}{ Signifikansi } \\
\cline { 2 - 4 } & $\mathrm{R}_{1}$ & $\mathrm{R}_{2}$ & $\mathrm{R}_{3}$ & \\
\hline Persentase karkas (\%) & $50,37 \pm 3,22$ & $48,04 \pm 0,08$ & $47,37 \pm 3,05$ & 0,42 \\
$\mathrm{pH}$ & $5,76 \pm 0,04$ & $5,75 \pm 0,06$ & $5,43 \pm 0,36$ & 0,17 \\
Keempukan (g/cm²) & $7,35 \pm 1,99^{\mathrm{b}}$ & $7,77 \pm 1,00^{\mathrm{b}}$ & $4,33 \pm 1,06^{\mathrm{a}}$ & 0,01 \\
Susut masak (\%) & $46,38 \pm 2,87$ & $46,81 \pm 4,06$ & $39,82 \pm 10,92$ & 0,33 \\
Daya mengikat & $35,66 \pm 2,43$ & $35,96 \pm 1,67$ & $32,86 \pm 1,18$ & 0,11 \\
air/DMA (\%) & 2 & 2 & 2 & - \\
Warna daging & 2 & 2 & 2 & - \\
Warna lemak & 2 & & 2 \\
\hline
\end{tabular}

Superscript huruf yang berbeda pada kolom yang sama menunjukkan perbedaan yang nyata $(\mathrm{P}<0,05)$

Pemberian pelet Indigofera zolingeriana sebanyak 5 dan $10 \mathrm{~g} / \mathrm{Kg} \mathrm{BB} / \mathrm{e} / \mathrm{h}$ tidak memberikan pengaruh yang nyata $(\mathrm{P}>0,05)$ terhadap persentase karkas. Hal ini disebabkan karena pakan yang diberikan sudah mampu memenuhi kebutuhan ternak dan sudah mengeksplor kapasitas genetik kambing Boerka dengan baik. Persentase karkas kambing Boerka pada penelitian ini berkisar antara 47,37-50,37 \%. Persentase karkas ini masih berada pada kisaran normal, dimana menurut Ensiminger (2002), karkas kambing berkisar antara $37-55 \%$ bobot badan.

Rataan nilai $\mathrm{pH}$ daging kambing pada penelitian ini berkisar antara 5.33-5.76 dan tidak ada perbedaan yang nyata antar perlakuan $(\mathrm{P}>0,05)$. Nilai $\mathrm{pH}$ yang diperoleh dalam penelitian ini hampir sama dengan nilai $\mathrm{pH}$ daging kambing Boerka yang dilaporkan Tarigan (2018), yaitu sebesar 5,72-5,88. Normalnya nilai pH menunjukkan bahwa semua ternak mendapatkan pakan dengan kualitas yang sama. Muchenje et al. (2011) menyatakan bahwa $\mathrm{pH}$ daging kambing menggambarkan tingkat stress ternak sebelum disembelih. Nilai $\mathrm{pH}$ yang tidak berbeda nyata pada penelitian ini menunjukkan bahwa pengkondisian ternak sebelum disembelih dan proses penyembelihan sudah dilakukan dengan metode yang baik dan sama untuk setiap ternak perlakuan.

Tingkat keempukan daging kambing Boerka yang diberi pelet Indigofera zolingeriana adalah 4,33-7,77. Pemberian pelet Indigofera zolingeriana sebanyak $10 \mathrm{~g} / \mathrm{kg}$ $\mathrm{BB} / \mathrm{e} / \mathrm{h}$ terbukti memberikan pengaruh yang nyata terhadap peningkatan keempukan daging kambing Boerka dibandingkan dengan kontrol $\left(\mathrm{R}_{1}\right)$. Nilai keempukan daging kambing yang tidak diberi pelet Indigofera zolingeriana adalah 7,35, atau tergolong agak alot. Suryati et al. (2008) menjelaskan bahwa daging dapat dikelompokkan menjadi 6 kelompok berdasarkan tingkat keempukan, yaitu daging yang sangat empuk (daya putus $\left.\mathrm{WB}<3,3 \mathrm{~kg} / \mathrm{cm}^{2}\right)$, empuk $\left(3,3-5 \mathrm{~kg} / \mathrm{cm}^{2}\right)$, agak empuk $\left(5-6,71 \mathrm{~kg} / \mathrm{cm}^{2}\right)$, agak alot $(6,71-$ $\left.8,2 \mathrm{~kg} / \mathrm{cm}^{2}\right)$, alot $\left(8,42-10,12 \mathrm{~kg} / \mathrm{cm}^{2}\right)$, dan sangat alot $\left(>10,12 \mathrm{~kg} / \mathrm{cm}^{2}\right)$. Pemberian pelet Indigofera $10 \mathrm{~g} / \mathrm{kg} \mathrm{BB} / \mathrm{e} / \mathrm{h}$ mampu meningkatkan nilai keempukan daging daripada pemberian pelet Indigofera $5 \mathrm{~g} / \mathrm{kg} \mathrm{BB} / \mathrm{e} / \mathrm{h}$ dengan nilai keempukan daging yang lebih rendah. Hal ini diduga karena kandungan flavenoid dalam Indigofera tersebut dapat mengaktifkan enzim lipase yang mampu mengubah lemak berlebih dalam tubuh menjadi asam lemak dan gliserol sehingga tidak terjadi penimbunan lemak dalam tubuh (Widyamanda et al. 2013). Semakin banyak pemberian pelet Indigofera maka semakin 
tinggi pula kandungan flaveniod yang dikonsumsi. Sel-sel lemak yang berada diantara selaput daging berpengaruh terhadap keempukan daging (Reny 2009).

Pemberian pelet Indigofera zolingeriana tidak memberikan pengaruh yang nyata $(\mathrm{P}>0,05)$ terhadap nilai susut masak, daya mengikat air, warna daging dan warna lemak. Rataan nilai susut masak yang diperoleh dalam penelitian ini adalah 39,82-46,81\%. Nilai ini hampir sama dengan nilai susut masak daging kambing Boerka yang dilaporkan oleh Tarigan (2018), yaitu sebesar 37,08-40,27\%. Susut masak merupakan persentase berkurangnya bobot daging akibat pemasakan. Sehingga, dapat dinyatakan bahwa semakin alot daging kambing angka penyusutan akibat pemasakan akan semakin rendah. Nilai susut masak daging yang tidak berbeda nyata menunjukkan bahwa pemberian pelet Indigofera zolingeriana sebanyak $10 \mathrm{~g} / \mathrm{kg} \mathrm{BB} / \mathrm{e} / \mathrm{h}$ mampu meningkatkan keempukan daging tanpa meningkatkan persentase susut masak. Bahkan secara numerik, pemberian pelet Indigofera zolingeriana sebanyak $10 \mathrm{~g} / \mathrm{kg} \mathrm{BB} / \mathrm{e} / \mathrm{h}$ mengurangi nilai susut masak sebesar $14,14 \%$ dibandingkan dengan control $\left(\mathrm{R}_{1}\right)$. Penambahan jumlah pemberian pelet Indigofera zolingeriana perlu diteliti lebih lanjut untuk mengurangi nilai susut masak dan peningkatan keempukan daging yang lebih optimal.

Daya Mengikat Air (DMA) daging direpresentasikan oleh jumlah $\mathrm{MgH}_{2} \mathrm{O}$ pada daging, dimana semakin tinggi $\mathrm{MgH}_{2} \mathrm{O}$ menunjukkan DMA semakin rendah. DMA yang rendah pada daging akan mengeluarkan banyak air ketika dimasak yang mengakibatkan membran seluler menjadi rusak dan memicu terjadinya degradasi protein (Shanks et al. 2002). DMA yang tidak berbeda nyata setiap perlakuan merupakan salah satu penyebab tidak terjadinya perbedaan susut masak daging kambing Boerka pada penelitian ini.

Warna daging dan lemak merupakan indikasi tingkat kualitas daging. Warna daging dan lemak pada penelitian ini tidak berbeda pada setiap perlakuan dengan skor 2 . Penilaian kualitas daging menggunakan color card menunjukkan bahwa daging kambing Boerka pada penelitian ini tergolong merah cerah, dimana warna ini biasanya disukai oleh konsumen. Warna daging yang tidak berbeda nyata disebabkan oleh nilai $\mathrm{pH}$ yang relatif sama. Prido et al. (2001) menyatakan bahwa daging kambing yang memiliki $\mathrm{pH}$ yang tinggi akan menyebabkan warna daging menjadi lebih gelap.

\section{KESIMPULAN}

Pemberian pelet Indigofera zolingeriana memberikan pengaruh yang nyata terhadap pertambahan bobot badan harian dan keempukan daging dengan dosis pemberian terbaik adalah $5 \mathrm{~g} / \mathrm{kg} \mathrm{BB} / \mathrm{e} / \mathrm{h}$. Pemberian pelet Indigofera zolingeriana tidak memberikan pengaruh yang nyata terhadap persentasi karkas, $\mathrm{pH}$, susut masak dan daya mengikat air daging kambing Boerka sehingga perlu dilakukan penelitian lebih lanjut.

\section{DAFTAR PUSTAKA}

AOAC. 2012. Official methods of analyses. 17th ed. Washington DC (USA): Association of Official Analythical Chemistry.

Aqsha GE, Purbowati E, Al-Baari AN. 2011. Komposisi kimia daging kambing kacang, peranakan etawah dan kejobong jantan pada umur satu tahun. Workshop Nasional Diversifikasi Pangan Daging Ruminansia Kecil.

Ensminger ME, Oldfield JE, Heinemann WW. 2002. Feeds and nutrition. 2nd ed. Illionist, California (USA): The Ensminger Publishing Company. 
Kim, IS, Jin SK, Yang V, Chu GM, Park V, Rashid RHI, Kim JY, Kang SN. 2013. Efficiency of tomato powder as antioxidant in cooked pork patties. Asian-Aust J Anim Sci. 26:1339-1346.

Martin GB, Ferasyi TR. 2010. Natural methods for increasing reproductive efficiency in small ruminants - the 'Clean, Green and Ethical' concept in action. Proceeding International Seminar Think Globally Act Locally: Entering The Global Market of Animal Health and Livestock Through Utilizing Local Resources Based on Green Vision. Banda Aceh (Indonesia): Faculty of Veterinary Medicine, Syiah Kuala University.

Muchenje V, Chulayo AY, Mwale M, Masika PJ. 2011. Effect of some medicinal plants on customer sensory characteristics of village chicken meat. Afr J Biotechnol. 10:815-820.

National Research Center. 2004. Nutrient requirement of small ruminants (sheep, goat, cervids, and new world camelids). Washington DC (USA): National Academic Press,

Nissen, H, Alvseike O, Bredholt S, Holck A, Nesbakken T. 2000. Comparison between the growth of Yersinia enterocolitica, Listeria monocytogenes, Escherichia coli O157:H7 and Salmonella spp in Ground Beef Packed by Three Commercially Used Packaging Techniques. Int J Food Microbiol. 59:211-220.

Palupi R, Abdullah L, Astuti DA, Sumiati. 2014. Potensi dan pemanfaatan tepung pucuk Indigofera sp sebagai bahan pakan substitusi bungkil kedelai dalam ransum ayam petelur. JITV. 19:210-219.

Park P, Goins R. 1994. In Situ Preparation of Fatty Acid Methyl Esters for Analysis of Fatty Acid Composition in Foods. J Food Sci. 59:1262-1266.

Reny DT. 2009. Keempukan daging dan faktor-faktor yang mempengaruhinya. Lampung (Indonesia): Balai Pengkajian Teknologi Pertanian Lampung.

Sánchez A, Djenane D, Torrescano G, Beltrán JA, Roncalés P. 2003. Antioxidant action of borage, rosemary, oregano, and ascorbic acid in beef patties packaged in modified atmosphere. J Food Sci. 68:339-344.

Steel RGD, Torrie JH. 1990. Prinsip dan prosedur statistika: Suatu pendekatan biometrik. Jakarta (Indonesia): PT Gramedia.

Suryati T, Arif II, Poli BN. 2008. Correlation and categories of meat tenderness based on equipment and panelis test. J Anim Prod. 3:188-193.

Tarigan A, Ginting SP, Arif II, Astuti DA, Abdullah L. 2018. Body weight gain, nutrients degradability and fermentation rumen characteristics of Boerka goat supplemented green concentrate pellets (GCP) based on Indigofera zollingeriana. Pak J Biol Sci. 21:87-94.

Thalib A. 2004. Uji efektivitas saponin buah Sapindus rarak sebagai inhibitor metanogenesis secara in vitro pada sistem pencernaan rumen. JITV. 9:164-171.

Widyamanda LP, Yunianto VD, Estiningdriati I. 2013. Pengaruh penambahan bangle (Zingiber cas-sumunar) dalam ransum terhadap total lipid dan kolesterol hati pada ayam broiler. Anim Agric J. 2:183-190.

Zhong RZ, Tan CY, Han XF, Tang SX, Tan ZL, Zeng B. 2009. Effect of dietary tea catechins supplementation in goats on the quality of meat kept under refrigeration. Small Rumin Res. 87:122-125. 